\title{
Perancangan Sistem Informasi Manajemen Gudang PT. X
}

\author{
Vini Aulia Zakiah Sodikin*, Reni Amaranti, Djamaludin \\ Prodi Teknik Industri, Fakultas Teknik, Universitas Islam Bandung, \\ Indonesia.
}

*viniauliazs@gmail.com, reniamaranti2709@yahoo.com,mas.jamal@gmail.com

\begin{abstract}
PT. X is a textbook publishing and printing company that produces according to customer requests. In supporting these production activities, the company has a raw material warehouse. Currently, inventory data collection activities in the raw material warehouse are carried out on different physical documents, so that changes in the amount of material inventory cannot be known automatically when goods enter or leave. This causes the decision-making process in material replenishment to be hampered and ultimately affects the production process. An alternative that can be done in solving the problem is to design a company warehouse management information system that can provide accurate information on the availability of raw materials. The research stages follow the stages of system development with the Throwaway Prototyping Method which consists of four main stages, namely planning, analysis, design, and implementation. The results obtained are a warehouse management information system in the form of an application prototype which consists of the administration of receiving goods, the status of inventory in the warehouse and the administration of releasing goods from the warehouse. The prototype was built based on the needs and desires of the company. The results of the prototype test showed that information on the amount of raw material inventory can be known in real time so the prototype development can proceed to the design and implementation stages of the actual system.
\end{abstract}

Keywords: warehouse management information system, Throwaway Prototyping methods, system request.

\begin{abstract}
Abstrak. PT. X merupakan perusahan penerbitan dan percetakan buku pelajaran yang melakukan produksi sesuai dengan permintaan pelanggan. Dalam mendukung kegiatan produksi tersebut, perusahaan memiliki gudang bahan baku. Saat ini aktivitas pendataan persediaan di gudang bahan baku dilakukan pada dokumen fisik yang berbeda, sehingga perubahan jumlah persediaan material tidak memungkinkan diketahui secara otomatis saat barang masuk atau keluar. Hal ini menyebabkan proses pengambilan keputusan dalam pengisian kembali material menjadi terhambat dan pada akhirnya berpengaruh juga pada proses produksi. Alternatif yang dapat dilakukan dalam menyelesaikan masalah adalah merancang sistem informasi manajemen gudang perusahaan yang dapat memberikan informasi ketersediaan bahan baku secara akurat. Tahapan penelitian mengikuti tahapan-tahapan pengembangan sistem dengan Metode Throwaway Prototyping yang terdiri dari empat tahapan utama yaitu perencanaan, analisis, perancangan, dan implementasi. Hasil yang diperoleh yaitu sistem informasi manajemen gudang dalam bentuk prototype aplikasi yang didalamnya terdiri dari administrasi penerimaan barang, status persediaan barang di gudang dan administrasi pengeluaran barang dari gudang. Prototype dibangun berdasarkan pada kebutuhan dan keinginan dari pihak perusahaan. Hasil pengujian prototype didapatkan bahwa informasi jumlah persediaan bahan baku dapat diketahui secara real time sehingga pengembangan prototype dapat dilanjutkan ke tahap perancangan dan implementasi pada sistem yang sebenarnya.
\end{abstract}

Kata Kunci: sistem informasi manajemen gudang, metode Throwaway Prototyping, kebutuhan sistem. 


\section{A. Pendahuluan}

Teknologi informasi yang semakin berkembang setiap harinya membuat beberapa perusahaan mulai melakukan perbaikan dan pembaharuan pada strategi bisnis yang sudah lama berjalan. Hal ini dilakukan untuk meningkatkan kinerja dan produktivitas serta memberikan pelayanan terbaik kepada konsumen. Salah satu perbaikan yang dilakukan adalah pada bagian gudang yang secara umum digunakan dalam aktivitas penerimaan, penyimpanan, perawatan dan distribusi barang [1]. Gudang memiliki beberapa peran, salah satunya sebagai tempat untuk menyimpan bahan baku [2].

PT. X merupakan perusahaan yang bergerak di bidang penerbitan dan percetakan. Dalam mendukung aktivitas percetakan tersebut, perusahaan memiliki gudang yang digunakan untuk menyimpan bahan baku baku seperti kertas, tinta, plat, dan bahan-bahan kimia yang biasanya digunakan dalam aktivitas percetakan buku. Secara umum, aktivitas yang terjadi di gudang bahan baku perusahaan diawali dengan penerimaan material yang sebelumnya telah dilakukan pembelian melalui dokumen purchase order, selanjutnya material tersebut diperiksa dan disimpan sementara di gudang sebelum dikirimkan ke bagian produksi.

Dilihat dari fenomena yang terjadi di perusahaan, perubahan jumlah stok material tidak memungkinkan diketahui secara otomatis karena dilakukan pendataan pada dokumen fisik yang berbeda [3]. Hal ini dapat mempengaruhi aktivitas produksi karena terhambatnya pengambilan keputusan untuk pengisian kembali bahan baku. Selain itu, ketidaktersediaan informasi mengenai status persediaan juga berdampak pada departemen PPIC yang tidak akan bisa memberi keputusan dalam menghitung waktu penyelesaian produk sesaat setelah mereka menerima pesanan sehingga waktu merespon pelanggan menjadi lebih lama. Berdasarkan uraian fenomena tersebut maka penelitian ini diperlukan untuk merancang suatu sistem informasi manajemen gudang yang sesuai dengan kebutuhan sehingga aktivitas perusahaan yang berkaitan dengan administrasi gudang bahan baku dapat berjalan lebih efektif dan efisien.

\section{B. Metodologi}

Sistem didefinisikan sebagai sekolompok komponen yang saling berhubungan dan memiliki batasan, bekerja sama dalam menggapai tujuan, memiliki masukan yang melewati proses transformasi dan menghasilkan keluaran [4]. Sedangkan informasi berkenaan dengan data yang sudah diproses menjadi bentuk yang berguna dan dapat dimanfaatkan oleh mereka yang membutuhkannya [5]. Adapun pengertian sistem informasi adalah gabungan manusia, perangkat lunak, perangkat keras, jaringan komunikasi, data dan kebijakan atau prosedur dalam mengumpulkan, memproses, menyimpan dan menyebarluaskan atau menyediakan informasi yang dibutuhkan untuk menyelesaikan pekerjaan [4].

Terdapat beberapa metode dalam melakukan pengembangan sistem informasi, salah satunya adalah Metode Throwaway Prototyping yang dimana rancangan prototype yang dihasilkan tidak akan digunakan pada sistem karena hanya mengandung beberapa detail yang cukup untuk menjelaskan kepada pengguna bagaimana masalah akan diselesaikan [6]. Metode Throwaway Prototyping memiliki fase atau tahapan yang dapat dilihat pada Gambar 1 .

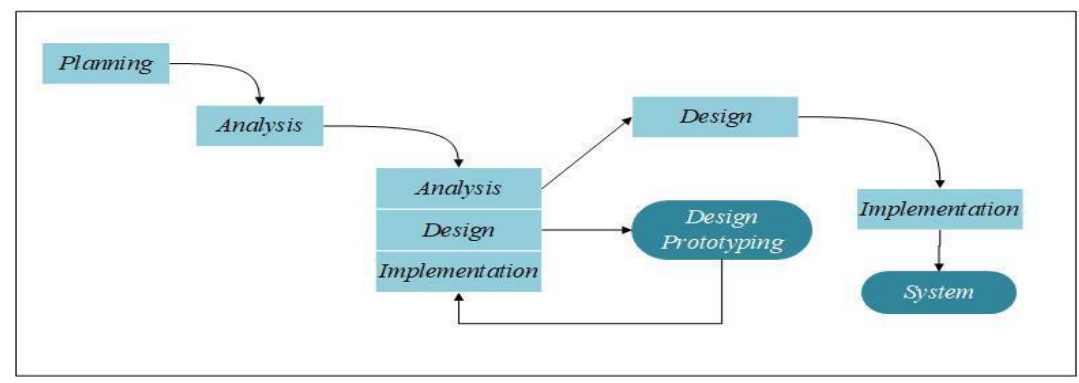

Gambar 1. Metode Throwaway Prototyping [6]

Pemodelan perancangan sistem digambarkan dengan Business Process Model and 
Notation 2.0 yang memodelkan proses bisnis perusahaan. Tujuan pemodelan menggunakan BPMN adalah menyajikan notasi yang mudah dimengerti oleh seluruh pelaku bisnis; dimulai dari sistem analis yang membuat rancangan hingga pengembang teknikal atau pembangun teknologi serta pengguna akhir yang mengontrol seluruh proses. Fungsi BPMN adalah sebagai jembatan kesenjangan antara rancangan proses dengan proses yang diimplementasikan [7]. Sedangkan pemodelan interaksi sistem digambarkan dengan Use Case Diagram yang mendeskripsikan tingkah laku dalam berbagai kondisi saat sistem menanggapi permintaan dari aktor [8]. Aktor utama memulai permintaan sistem berdasarkan tujuan yang ingin dicapai kemudian sistem merespon permintaan tersebut. Terakhir, pemodelan data digambarkan dengan Entity Relationship Diagram (ERD) merupakan suatu gambar yang menunjukkan bahwa suatu informasi diciptakan, didokumentasikan dan digunakan oleh sistem [6].

Pengembangan sistem informasi dilakukan pada bagian gudang bahan baku perusahaan. Adapun pengertian gudang adalah bangunan yang digunakan dalam menyimpan barang [9]. Utamanya, gudang seharusnya menjadi titik pengiriman dimana semua barang-barang yang diterima, sebisa mungkin dikirim dengan cepat, efektif dan efisien [2]. Perkembangan teknologi secara signifikan dapat meningkatkan produktivitas dan pemanfaatan gudang, mengurangi biaya serta meningkatkan kepuasan konsumen. Untuk itu, jika perusahaan ingin bersaing diperlukan sistem manajemen gudang yang real-time. Sistem manajemen gudang dapat memproses data dengan cepat, mengetahui pergerakan koordinat didalam gudang, membuat laporan serta menangani volume transaksi yang besar pada operasi e-commerce [2]. Pengelolaan pergudangan juga mempertimbangkan kontrol stok barang yang dapat berguna dalam memberikan informasi mengenai letak dan jumlah stok di gudang dan memberikan jalur pengambilan yang optimal [1].

\section{Hasil dan Pembahasan}

Penelitian dilakukan di Departmen Administrasi dan Keuangan, bagian Administrasi Proyek, yang membawahi langsung gudang bahan baku perusahaan. Tahapan pertama dalam pengembangan sistem informasi adalah perencanaan sistem informasi dimana pada tahapan ini dilakukan identifikasi pada sistem lama dan mengetahui pembaharuan yang dibutuhkan (system request) sebagai dasar pengembangan sistem baru yang dapat dilihat pada Tabel 1.

Tabel 1. System Request Aplikasi Manajemen Gudang Baku

\section{System Request - Aplikasi Manajemen Gudang Bahan Baku}

Sponsor proyek: Bagian Gudang Bahan Baku PT. X

Kebutuhan Bisnis: Pegawai dapat menyimpan data pada sebuah database sehingga mempermudah dalam hal:

- Kegiatan transaksi keluar-masuk bahan baku.

- Kegiatan pembuatan laporan transaksi.

Persyaratan bisnis: Adapun fungsi spesifik yang harus dimiliki oleh sistem adalah:

- Sistem dapat menghitung perubahan stok bahan baku.

- Sistem dapat diakses oleh bagian-bagian yang membutuhkan informasi mengenai bahan baku.

Nilai bisnis: Dengan dibangunnya sistem maka lama waktu yang dihabiskan untuk mengetahui stok bahan baku tidak sampai satu menit. Hal ini dapat memperpendek waktu dalam merespon pesanan konsumen.

Isu khusus dan batasan: Sistem dibutuhkan sesegera mungkin.

Tahapan kedua pengembangan sistem adalah analisis sitem informasi, dimana pada tahapan ini dilakukan analisis terhadap proses bisnis perusahaan, analisis kebutuhan sistem secara fungsional dan nonfungsional serta pemodelan perancangan logis. Proses bisnis bagian Administrasi Proyek dapat dilihat pada Gambar 2 dimana didalamnya terdapat gudang bahan baku dan purchasing. 


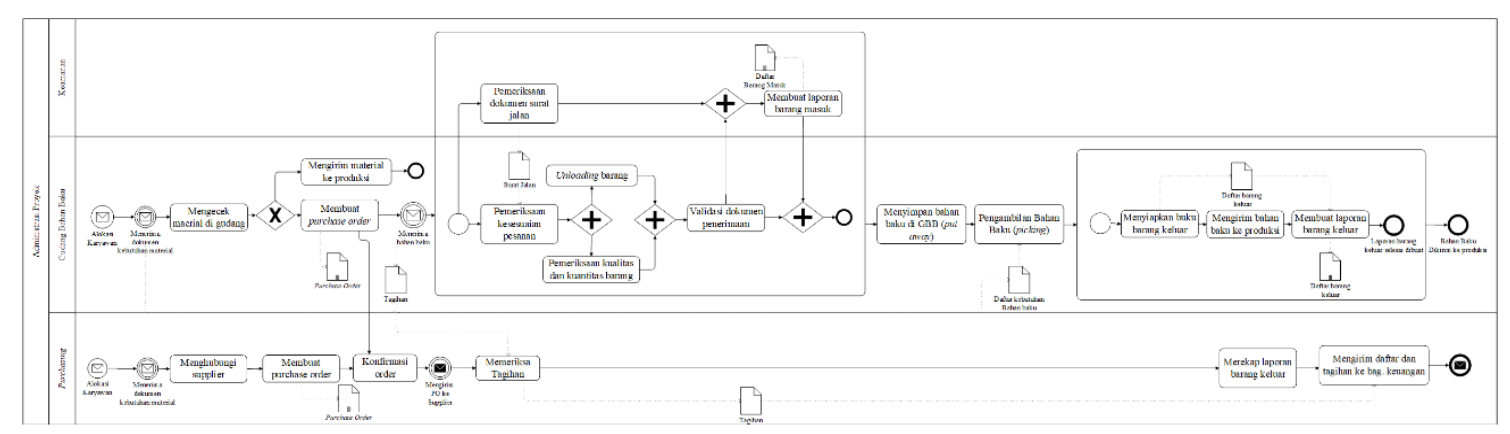

Gambar 2. Proses Bisnis Administrasi Proyek

Analisis kebutuhan fungsional berisikan proses-proses yang akan dilakukan oleh sistem dan mengandung informasi-informasi apa saja yang harus ada dan ditampilkan oleh sistem. Kebutuhan fungsional didefinisikan oleh beberapa bagian terkait yaitu PPIC, purchasing, gudang bahan baku serta administrasi dan keuangan (Tabel 2). Selain kebutuhan fungsional, ditentukan juga kebutuhan non fungsional yaitu kebutuhan yang berkaitan dengan perilaku sistem atau kebutuhan operasional sistem (Tabel 3).

Tabel 2. Kebutuhan Fungsional Sistem

\begin{tabular}{|c|c|c|}
\hline Bagian & No & Kebutuhan Fungsional Sistem \\
\hline \multirow{2}{*}{ Seluruh Bagian } & 1 & Sistem menyediakan fitur $\log \operatorname{In}$ \\
\hline & 2 & Sistem dapat menampilkan stok bahan baku. \\
\hline \multirow{4}{*}{ PPIC } & 1 & Sistem dapat menyimpan data material. \\
\hline & 2 & $\begin{array}{l}\text { Sistem dapat membantu dalam membuat dan menyimpan } \\
\text { dokumen Manufacturing Order. }\end{array}$ \\
\hline & 3 & $\begin{array}{l}\text { Sistem dapat membantu dalam membuat dan menyipan } \\
\text { dokumen Purchase Requisition. }\end{array}$ \\
\hline & 4 & Sistem menyediakan fitur untuk mengedit data pegawai. \\
\hline \multirow{4}{*}{ Purchasing } & 1 & Sistem dapat menyimpan data vendor baru. \\
\hline & 2 & $\begin{array}{l}\text { Sistem dapat membantu dalam membuat dan menyimpan } \\
\text { dokumen Purchase Order. }\end{array}$ \\
\hline & 3 & $\begin{array}{l}\text { Sistem dapat menampilkan laporan transaksi bahan baku dan } \\
\text { Purchase Order. }\end{array}$ \\
\hline & 4 & Sistem menyediakan fitur untuk mengedit data pegawai. \\
\hline \multirow{4}{*}{ Gudang Bahan Baku } & 1 & $\begin{array}{l}\text { Sistem dapat membantu dalam membuat dan menyimpan data } \\
\text { penerimaan dan pengeluaran bahan baku. }\end{array}$ \\
\hline & 2 & $\begin{array}{l}\text { Sistem dapat menampilkan laporan transaksi bahan baku masuk } \\
\text { dan keluar. }\end{array}$ \\
\hline & 3 & Sistem dapat menyimpan dan mengubah data pegawai. \\
\hline & 4 & $\begin{array}{l}\text { Sistem dapat membantu dalam membuat dan menyipan } \\
\text { dokumen Purchase Requisition. }\end{array}$ \\
\hline \multirow{4}{*}{ Administrasi \& Keuangan } & 1 & $\begin{array}{l}\text { Sistem dapat membantu dalam membuat dokumen untuk } \\
\text { mengelola tagihan dari vendor. }\end{array}$ \\
\hline & 2 & Sistem dapat menampilkan laporan transaksi bahan baku keluar. \\
\hline & 3 & Sistem dapat melihat data vendor. \\
\hline & 4 & Sistem menyediakan fitur untuk mengedit data pegawai. \\
\hline
\end{tabular}


Tabel 3. Kebutuhan Non-Fungsional Sistem

\begin{tabular}{|c|c|}
\hline \multicolumn{2}{|c|}{ Kebutuhan Non-Fungsional } \\
\hline \multirow{7}{*}{ Operasional } & $\begin{array}{l}\text { - Processor: intel(R) core(TM) i7-4720HQ } \quad \text { CPU } \\
\text { @2.60GHz }\end{array}$ \\
\hline & - Harddisk: 1TB \\
\hline & - RAM: 8 GB \\
\hline & - Sistem operasi Windows 10. \\
\hline & - Microsoft Access 2016. \\
\hline & - Jaringan LAN. \\
\hline & - Perangkat keras keyboard, mouse dan printer. \\
\hline Keamanan & $\begin{array}{l}\text { Sistem aplikasi maupun database dilengkapi kata sandi } \\
\text { dan hanya bisa diakses oleh staf terkait. }\end{array}$ \\
\hline Kinerja & $\begin{array}{l}\text { Waktu pemrosesan transaksi, stok barang dan laporan } \\
\text { dapat dijalakan hanya dalam satu menit. }\end{array}$ \\
\hline
\end{tabular}

Proses selanjutnya adalah mentransformasikan kebutuhan fungsional sistem ke dalam bentuk pemodelan logis. Gambar 3 menampilkan pemodelan interaksi sistem sistem logis menggunakan Use Case Diagram yang didalamnya tedapat empat aktor utama yaitu PPIC, purchasing, gudang bahan baku serta administrasi dan keuangan.

Pemodelan perancangan proses logis digambarkan dengan Business Process Modeling and Notation 2.0. Proses diawali oleh pembuatan jadwal induk produksi oleh bagian PPIC. Setelah membuat jadwal induk produksi, PPIC melakukan perencanaan kebutuhan material untuk produksi buku yang dipesan. Setelah kebutuhan material dibuat, PPIC mengecek ketersediaan stok bahan baku melalui sistem. Jika bahan baku yang dibutuhkan tersedia maka dibuatkan dokumen Manufacturing Order berdasarkan dokumen kebutuhan material. Namun jika tidak tersedia, maka PPIC mengirimkan Purchase Requisition ke bagian Purchasing. Setelah diterima, Purchasing meng-hubungi vendor-vendor yang biasa menyediakan material. Purchasing melakukan negosiasi dengan vendor mengenai harga dan waktu pengiriman material. Jika tidak menemukan kesepakatan, maka purchasing menghubungi vendor lain. Ketika vendor dan Purchasing sudah sepakat dalam segala hal, maka purchasing membuat dokumen purchase order dan mengirimkan dokumen tersebut ke vendor melalui e-mail.

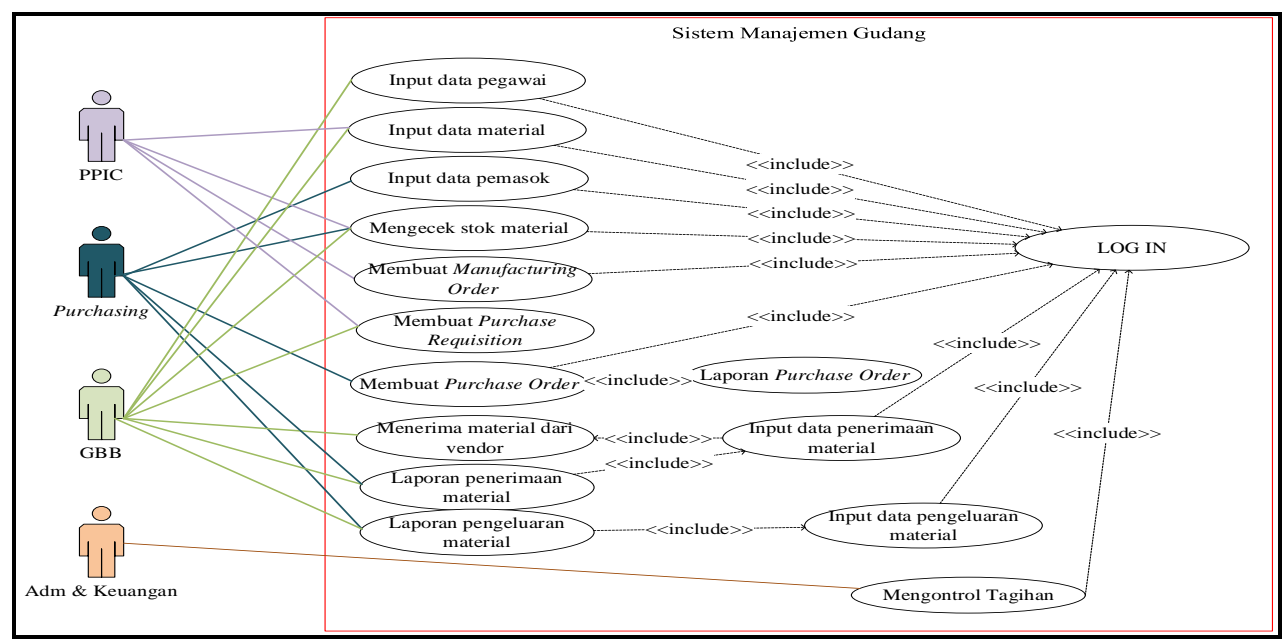

Gambar 3. Pemodelan Kebutuhan Sistem Logis

Material bahan baku yang dibeli dikirimkan oleh vendor dan diterima langsung oleh bagian gudang bahan baku. Selain material, terdapat dokumen surat jalan, delivery order dan tagihan yang dikirimkan oleh vendor. Pada kegiatan persiapan penerimaan material dilakukan 
pemeriksaan terhadap seluruh dokumen tersebut baru setelah itu dilakukan pembongkaran (unloading). Setelah dilakukan pembongkaran maka dilakukan pengecekan kesesuaian pesanan dan pengecekan kualitas material. Jika terdapat material yang tidak sesuai dan memiliki kecacatan yang lumayan besar maka material tidak akan diterima dan akan dikembalikan. Setelah material melewati proses pengecekan, maka dilakukan pencatatan barang masuk untuk memperbaharui informasi stok persediaan dan mengirimkan laporan penerimaan material ke vendor melalui e-mail. Baru setelahnya barang disimpan ditempat yang sudah ditentukan.

Manufacturing Order yang dibuat oleh PPIC dan beberapa permintaan bahan baku dasar dari bagian produksi diterima oleh bagian gudang bahan baku. Jika stok barang yang dibutuhkan tidak tersedia, bagian gudang dapat membuat dokumen Purchase Requisition untuk melakukan pengadaan barang. Jika bahan baku tersedia, maka bagian gudang akan membuat dokumen Delivery Order sebagai bukti pengeluaran barang dari gudang. Hal ini dilakukan untuk memperbaharui informasi stok persediaan bahan baku. Setelah itu, dilakukan pencarian dan pengambilan material yang diperlukan untuk selanjutnya dikirim ke bagian produksi.

Bagian purchasing melakukan pemeriksaan terhadap penggunaan material melalui tagihan dari supplier, dokumen penerimaan dan pengeluaran barang. Hal ini dilakukan karena terdapat jenis pembayaran yang berbeda pada beberapa kategori barang. Setelah tagihan diperiksa, tagihan diserahkan ke bagian Keuangan untuk dibuatkan dokumen Billing untuk mempermudah dalam pendokumentasian tagihan dari pemasok. Selanjutnya, untuk material yang menggunakan sistem laku bayar pembayaran dilakukan dengan sejumlah barang yang terpakai dan dapat dilihat pada laporan pengeluaran barang yang dapat diakses langsung oleh bagian Keuangan. Pemodelan perancangan proses logis dapat dilihat pada Gambar 4.

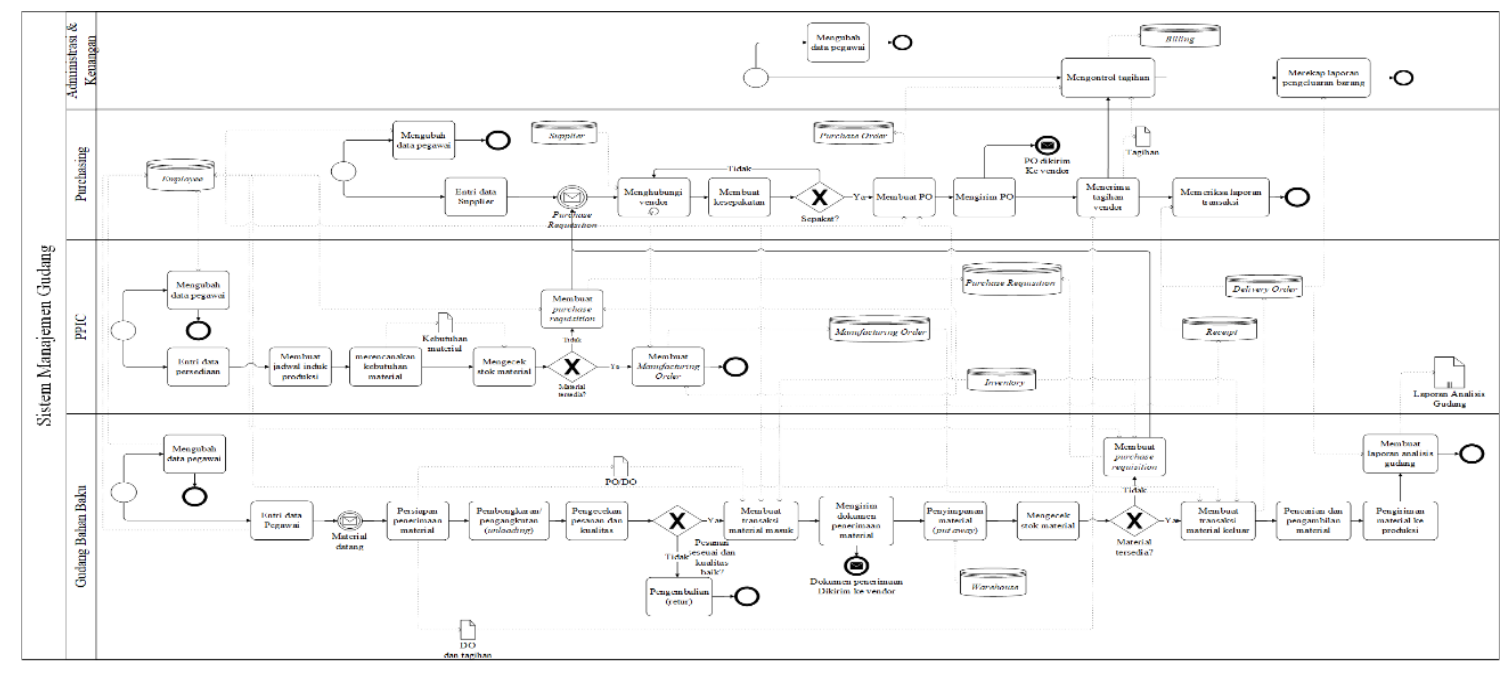

Gambar 4. Pemodelan Perancangan Proses Logis

Pemodelan data logis menggambarkan entitas-entitas yang nantinya menjadi dasar dalam membangun basis data. Dalam pemodelan data logis terdapat beberapa entitas didalamnya, seperti Employee, Purchase Requisition, Purchase Requisition Details, Purchase Order, Purchase Order Details, Delivery Order, Delivery Order Details, Receipt, Receipt Details, Manufacturing Order, Manufacturing Order Details, Billing, Inventory, Warehouse dan Supplier. Pemodelan perancangan data logis dapat dilihat pada Gambar 5. 


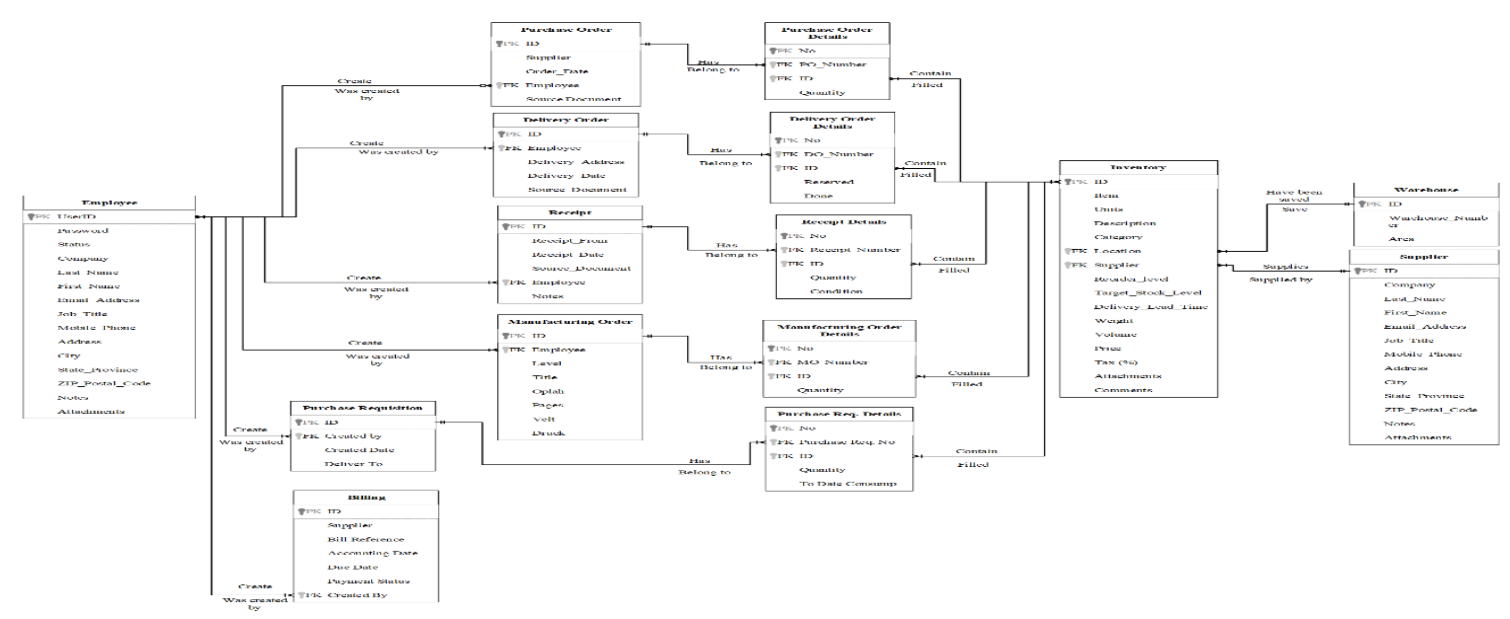

Gambar 5. Pemodelan Perancangan Data Logis

Tahapan ketiga pengembangan sistem adalah perancangan sistem informasi. Tahapan ini diawali dengan memodelkan data fisik dari entitas-entitas yang sebelumnya dimodelkan pada perancangan logis. Pada pemodelan data fisik, setiap atribut pada entitas ditentukan jenis tipe datanya dan penamaan atribut disesuaikan dengan kebutuhan pada basis data. Perancangan data fisik dapat dilihat pada Gambar 6.

Setelah itu, dilanjutkan dengan membuat rancangan proses fisik yang menggambarkan proses yang nantinya berjalan pada sistem yang baru. Pada perancangan proses fisik, aktivitasaktivitas yang dilakukan didalam aplikasi digambarkan dengan task yang didalamnya terdapat simbol task types User. Perancangan proses fisik dapat dilihat pada Gambar 7.

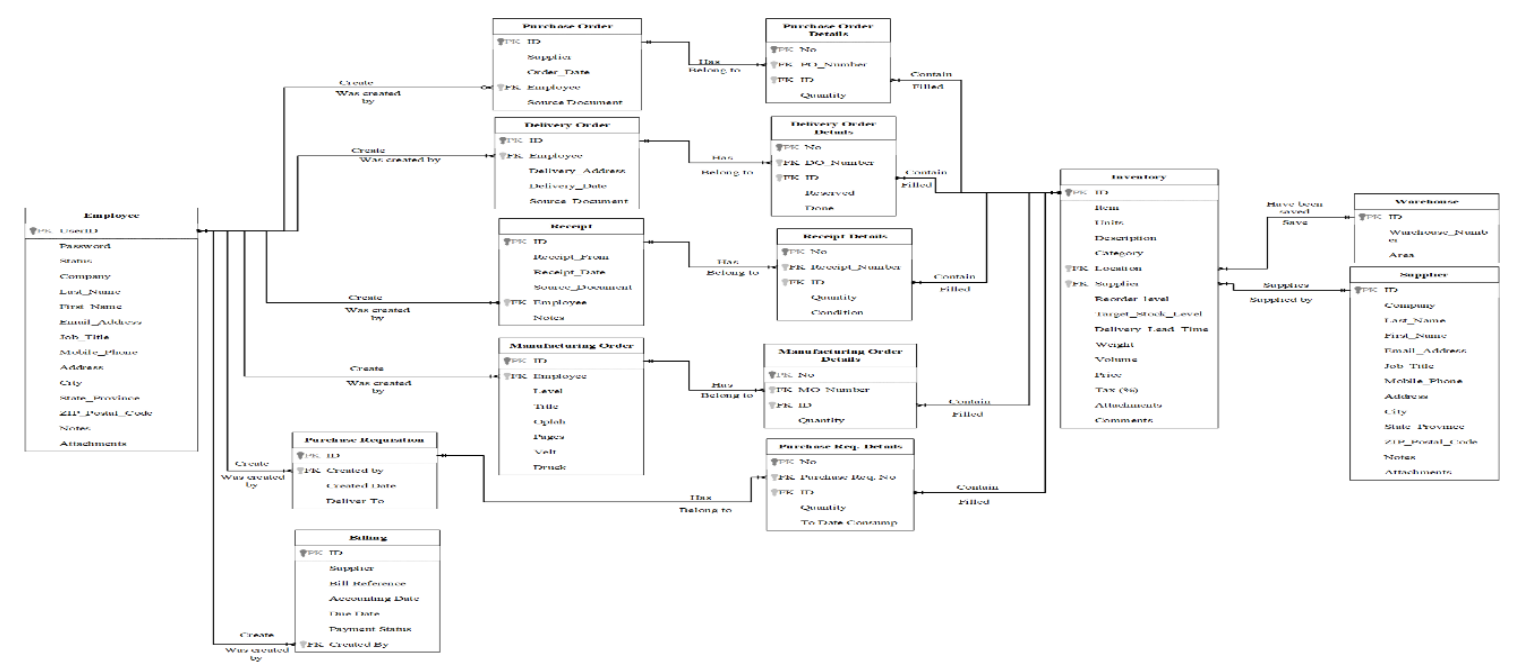

Gambar 6. Perancangan Data Fisik 


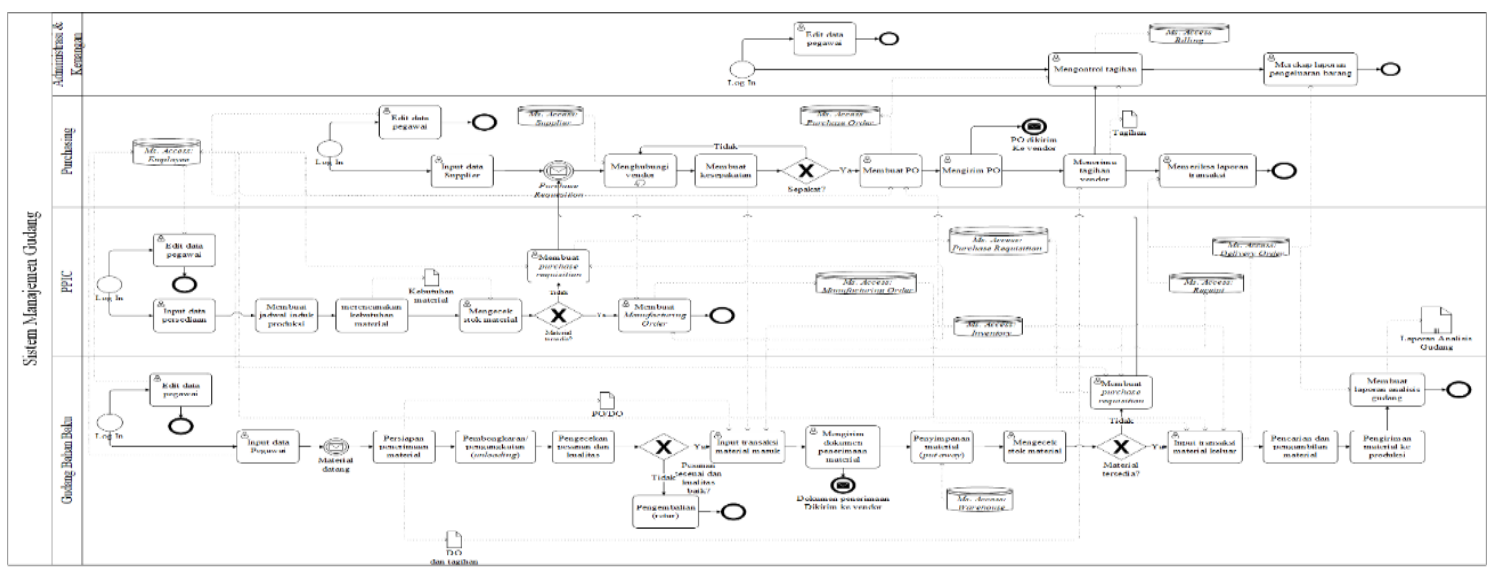

Gambar 7. Perancangan Proses Fisik

Proses terakhir dalam tahapan perancangan adalah membuat rancangan antarmuka untuk form-form yang dibutuhkan pada sistem dan merancangan arsitektur sistem. Adapun arsitektur yang dipilih adalah arsitektur client-server 2-tier. Arsitektur client-server 2-tier dipilih karena sistem yang dikembangkan memiliki skala yang tidak terlalu besar dan perangkat lunak basis data yang digunakan adalah Microsoft Access. Skema arsitektur client-server 2-tier pada pengembangan sistem informasi manajemen gudang dijelaskan pada Gambar 8 .

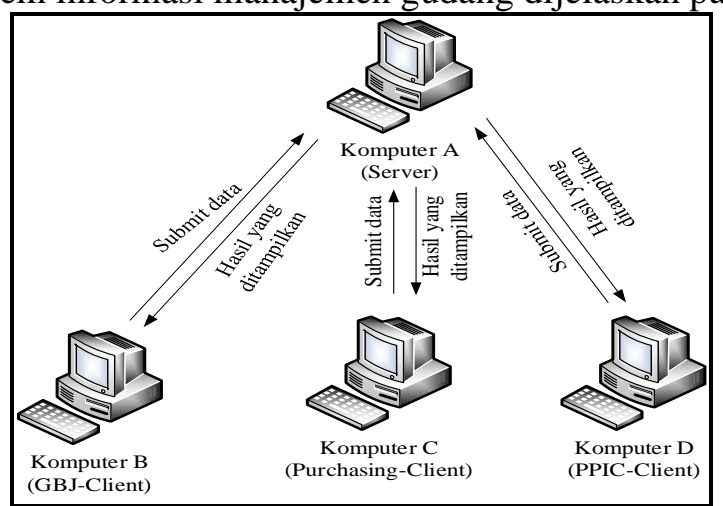

Gambar 8. Perancangan Arsitektur Client-Server 2-Tier

Tahapan akhir dalam pengembangan sistem adalah implementasi sistem informasi namun pada penelitian hanya dibatasi sampai proses pembangunan basis data dan pembangunan antarmuka sistem. Basis data dibangun didasarkan pada entitas-entitas yang sebelumnya telah didefinisikan pada perancangan data fisik. Sedangkan untuk antarmuka sistem dibangun sesuai dengan rancangan antarmuka sistem pada tahapan perancangan sebelumnya. Beberapa contoh rancangan antarmuka sistem dapat dilihat pada Gambar 9. 


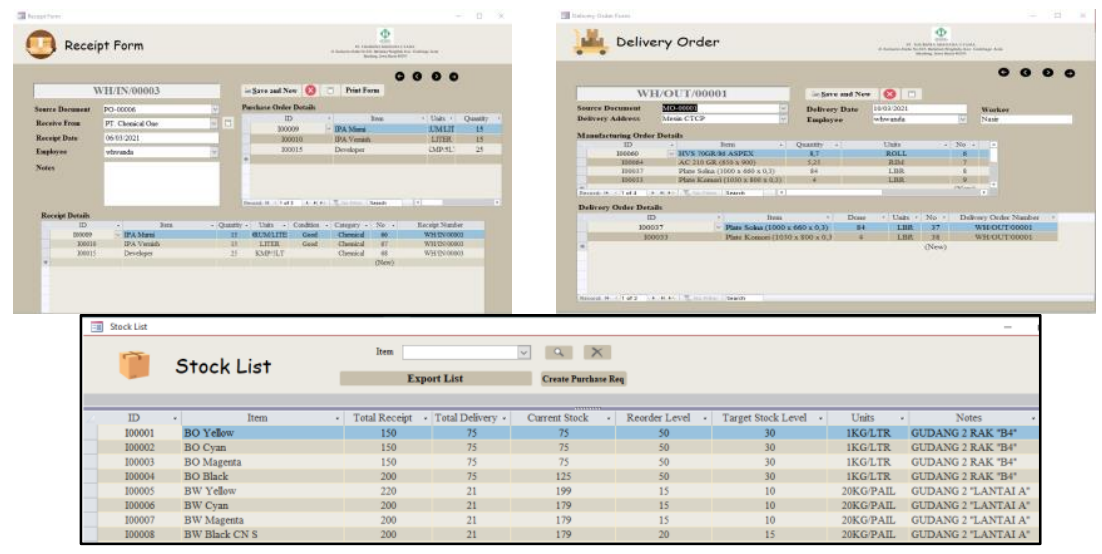

Gambar 9. Contoh Antarmuka Sistem

Secara umum, penelitian ini menghasilkan rancangan sistem informasi manajemen gudang (dalam bentuk prototype) yang dapat menyelesaikan beberapa permasalahan berkaitan dengan aliran informasi di gudang bahan baku dan menghambat aktivitas perusahaan. Dengan dibuatkannya prototype aplikasi dapat terlihat beberapa proses administrasi gudang menjadi lebih singkat dan data yang disimpan menjadi lebih tersusun dan terstruktur karena disediakan basis data. Adanya basis data sebagai media penyimpanan membantu bagian-bagian lain untuk mencari dan mendapatkan informasi yang mereka butuhkan dalam waktu yang singkat. Selain itu, data yang tersimpan juga memiliki keamanan yang cukup karena dilakukan pembagian hak akses yang berbeda-beda untuk setiap bagian sesuai dengan kebutuhan sistem sebelumnya.

Pengembangan sistem dilakukan dengan tahapan pada Metode Throwaway Prototyping dimana prototype yang dihasilkan pada penelitian ini tidak akan digunakan (dibuang). Sistem yang baru akan dibangun dengan melakukan perancangan ulang pada basis data (perancangan data fisik), perancangan proses fisik dan perancangan antarmuka yang lebih baik dari sebelumnya (prototype). Selain itu, perancangan arsitektur sistem juga mulai digambarkan secara lebih mendetail. Setelahnya, basis data dan antarmuka sistem mulai dibangun kembali dan akan diimplementasikan pada sistem yang sebenarnya.

\section{Kesimpulan}

Dari hasil penelitian mengenai perancangan sistem informasi manajemen gudang dapat ditarik beberapa kesimpulan:

1. Sistem manajemen gudang yang dibutuhkan oleh perusahaan adalah sistem yang dapat membantu dalam administrasi pergudangan. Administrasi pergudang an tersebut meliputi administrasi penerimaan barang, stok persediaan barang dan administrasi pengeluaran barang. Selain itu, beberapa dokumen yang berkaitan dengan aktivitas keluar-masuk barang dapat dibuat dan dikontrol dengan baik karena adanya integrasi pada beberapa bagian perusahaan, seperti PPIC, purchasing, keuangan dan gudang bahan baku.

2. Sistem informasi gudang yang dirancang didasarkan pada dokumen system request dan kebutuhan-kebutuhan fungsional sistem dari setiap bagian. Kebutuhan-kebutuhan fungsional sistem tersebut diolah yang dimulai dengan proses atau tahapan perencanaan, analisis, perancangan dan pembangunan hingga akhirnya menghasilkan sebuah prototype aplikasi manajemen gudang. Dari hasil pengujian, prototype sudah dapat memenuhi kebutuhan dan keinginan pihak gudang bahan baku seperti informasi mengenai stok persediaan yang dapat diketahui secara real time sehingga pengembangan prototype dapat diteruskan ke tahapan perancangan dan implementasi pada sistem sebenarnya. 


\section{Acknowledge}

Saya ucapkan terima kasih kepada Ibu Reni Amaranti, S.T., M.T., IPM. dan Bapak Djamaludin, S.T., M.A.B., yang telah menyediakan waktu, tenaga dan pikiran dalam membimbing penelitian ini. Tak lupa ucapan terima kasih juga saya berikan kepada Bapak Wanda dan karyawankaryawan PT. X yang bersedia menjadi narasumber dalam penelitian.

\section{Daftar Pustaka}

[1] S. Pandingan, Operasional Manajemen Pergudangan. Jakarta: Mitra Wacana Media, 2017.

[2] G. Richards, Warehouse Management: A Complete Guide to Improving Efficiency and Minimizing Costs in the Modern Warehouse, vol. 53, no. 9. 2014.

[3] A. Nurrahman, O. Rukmana, and I. A. Fauzi, "Perancangan Sistem Informasi Gudang Barang Jadi Di PT Remaja Rosdakarya," Ethos J. Penelit. dan Pengabdi. Kpd. Masy., vol. 7, no. 1, pp. 143-150, 2019.

[4] J. A. O'Brien and G. M. Marakas, Introduction to Information Systems, 15th ed. McGraw Hill Irwin, 2010.

[5] K. C. Laudon and J. P. Laudon, Management Information Systems, 15th ed. Harlow: Pearson Education Limited, 2017.

[6] A. Dennis, B. H. Wixom, and R. M. Roth, Systems Analysis And Design, 6th ed. USA: Wiley, 2014.

[7] O. M. Group, Business Process Model and Notation (BPMN). Needham: Object Management Group, Inc., 2011.

[8] J. F. George and J. S. Valacich, Modern Systems Analysis and Design - 8th Edition, 8th ed. USA: Pearson, 2017.

[9] J. Warman, Manajemen Pergudangan. Jakarta: Pustaka Sinar Harapan, 2018. 